\title{
Strategi Kampanye Gubernur Basuki Tjahaja Purnama-Djarot Saiful Hidayat Dalam Menghadapi Pilkada Dki Jakarta 2017
}

\author{
Rahmadya Putra Nugraha, Anastasya Christy Puspitasari \\ Fakultas Ilmu Komunikasi, Universitas Mercu Buana \\ Jl. Meruya Selatan No.1, RT.4/RW.1, Meruya Sel., Kembangan, Kota Jakarta Barat, Daerah \\ Khusus Ibukota Jakarta 11650 \\ anaztasyaichi93@gmail.com,rahmadya.putra@gmail.com
}

\begin{abstract}
The selection of the 2017 DKI Jakarta governor was attended by 3 candidates, including the pair Agus Harimurti - Sylviana Murni, the pair Basuki Tjahaja Purnama - Djarot Saiful Hidayat and the couple Anies Baswedan - Sandiaga Uno. Basuki Tjahaj Purnama Djarot Saiful Hidayat is a pair of incumbent governors who again competed in this gubernatorial election. The researcher focused on research to find out how the strategy used by the incumbent governor pair in facing the 2017 DKI Jakarta gubernatorial election. In this case, the author uses the Constructivist paradigm, namely, the truth of a social reality seen as a result of social construction, and the truth of a social reality is relative. The type of research used is descriptive, which describes a social situation as it is by using a qualitative descriptive analysis method. Based on this research regarding the campaign strategy of Basuki Tjahaja Purnama - Djarot Saiful Hidayat in facing the gubernatorial election, the researchers concluded that the pair Basuki Tjahaja Purnama - Djarot Saiful Hidayat possessed and re-demonstrated the real program that was directly felt by the community and also maximized the entire media to socialize their upcoming programs.
\end{abstract}

Keywords: incumbent, election, campaign

\begin{abstract}
Abstrak
Pemilihan gubernur DKI Jakarta 2017 diikuti oleh 3 pasangan calon antara lain pasangan Agus Harimurti - Sylviana Murni, Basuki Tjahaja Purnama - Djarot Saiful Hidayat dan Anies Baswedan - Sandiaga Uno. Pasangan Basuki Tjahaj Purnama - Djarot Saiful Hidayat adalah pasangan gubernur petahana yang kembali bersaing dalam pemilihan gubernur ini. Peneliti memfokuskan penelitian untuk mengetahui bagaimana strategi yang digunakan oleh pasangan gubernur petahana dalam menghadapi pemilihan gubernur DKI Jakarta 2017 ini. Dalam hal ini, penulis menggunakan paradigma Konstruktivis yaitu, kebenaran suatu realitas sosial dilihat sebagai hasil konstruksi sosial, dan kebenaran suatu realitas sosial bersifat relatif. Tipe penelitian yang digunakan dalam penelitian yaitu deskriptif, yang menggambarkan suatu keadaan sosial secara apa adanya dengan menggunakan metode analisis deskriptif kualitatif. Berdasarkan penelitian ini mengenai strategi kampanye Basuki Tjahaja Purnama - Djarot Saiful Hidayat dalam menghadapi pemilihan gubernur, maka peneliti membuat kesimpulan bahwa pasangan Basuki Tjahaja Purnama - Djarot Saiful Hidayat memiliki dan menunjukkan kembali program nyata yang sudah dirasakan langsung oleh masyarakat dan juga pasangan ini memaksimalkan seluruh media untuk mensosialisasikan program mereka yang akan datang.
\end{abstract}

Kata Kunci: kampanye, petahana, pilkada 


\section{Pendahuluan}

Pemilu yang diadakan pada tahun 2014 adalah pemilu yang kesebelas kalinya semenjak Indonesia merdeka. Kembalinya sistem multi partai ini menjadikan para kontestan calon dihadapkan pada sebuah kenyataan, bahwa persaingan untuk mampu merebut, memuaskan dan meyakinkan pemilih semakin ketat.Tujuan akhir dari persaingan antar partai ini adalah membawa pemilih ke tempat pemungutan suara (TPS) sampai akhirnya mencoblos satu partai. Guna memenangkan kompetisi di ajang pemilu, para kontestan partai politik saling bersaing satu sama lain dengan menerapkan berbagai strategi komunikasi politik yang jitu.

Strategi komunikasi politik yang dilakukan oleh partai politik terhadap masyarakat sangat diperlukan dalam menghadapi sebuah pemilihan umum. Keberhasilan suatu strategi komunikasi politik oleh partai politik dalam merencanakan dan melaksanakan, akan ikut berperan pada hasil perolehan suara partai politik dalam pemilu. Strategi komunikasi politik sangat penting untuk dianalisis. Karena strategi tersebut tidak hanya menentukan kemenangan politik pesaing, tetapi juga akan berpengaruh terhadap perolehan suara partai (Firmanzah, 2008).

Setiap Daerah di indonesia mempunyai pemimpin diantaranya adalah Gubernur, Bupati dan Walikota. Untuk memilih pemimpin tersebut maka pemerintah pusat melaksanakan pemilihan langsung yang dilakukan oleh rakyat dalam satu daerah.Pemilihan ini biasa disebut sebagai "Pilkada". Pemilihan kepala daerah atau yang biasa disebut Pilkada atau Pemilukada dilakukan secara langsung oleh penduduk daerah administratif setempat yang memenuhi syarat. Pemilihan kepala daerah dilakukan satu paket bersama dengan wakil kepala daerah. Kepala daerah dan wakil kepala daerah yang antara lain Gubernur dan wakil gubernur untuk provinsi, Bupati dan wakil bupati untuk kabupaten, serta Wali kota dan wakil wali kota untuk kota. Pada tahun 2011, terbit undang-undang baru mengenai penyelenggara pemilihan umum yaitu Undang-Undang Nomor 15 Tahun 2011.Di dalam undang-undang ini, istilah yang digunakan adalah Pemilihan Gubernur, Bupati, dan Wali Kota (http://www.academia.edu/3654706).

Tiga bakal calon gubernur yang akan bersaing pada Pemilihan Kepala Daerah (Pilkada) DKI Jakarta 2017 telah mendaftarkan diri ke Komisi Pemilihan Umum (KPU) DKI Jakarta. Salah satunya adalah bakal calon gubernur petahana Basuki Tjahaja Purnama alias Ahok. Meski berstatus petahana, ini merupakan pertama kalinya ia maju sebagai calon gubernur DKI. Pada Pilkada sebelumnya, Basuki Tjahaja Purnama masih berstatus sebagai calon wakil gubernur mendampingi Joko Widodo.

Selama menjabat Gubernur DKI, Basuki Tjahaja Purnama tak bergabung dengan partai manapun. Dalam persiapan menghadapi Pilkada DKI Jakarta 2017, Basuki Tjahaja Purnama sempat menyatakan ingin maju melalui jalur independen. Melalui bantuan kelompok relawannya, "Teman Ahok", ia sudah memiliki modal 1 juta data KTP. Namun dalam perkembangannya, Basuki Tjahaja Purnama akhirnya membatalkan niatnya maju melalui jalur independen menyusul datangnya dukungan dari Hanura, Golkar, dan Nasdem. Sehari sebelum 
dibukanya pendaftaran oleh KPU DKI, dukungan kepadanya juga datang dari PDIP.

Basuki Tjahaja Purnama kemudian mendaftar sebagai calon gubernur dengan diusung empat partai. Pada Pilkada DKI 2017, Basuki Tjahaja Purnama menyebut secara garis besar visi misinya sama dengan visi misi saat dirinya maju mendampingi Joko Widodo pada Pilkada DKI Jakarta 2012. "Kami ingin kepala, dompet, sama perut warga Jakarta penuh," ujar Basuki di Balai Kota Jalan Medan Merdeka Selatan, Jumat (23/9/2016) (https://ahokdjarot.id/media).

Otak penuh berarti pendidikan terjangkau dan berkualitas, mengembalikan tempat ibadah menjadi pusat kegiatan masyarakat, dan membuka semua data secara transparan guna meningkatkan partisipasi publik dengan berbagai program e-government. Kemudian perut penuh berarti masyarakat menikmati makanan yang aman dan bergizi serta memperkuat BUMD sebagai penyeimbang harga dan menjaga suplai kebutuhan.Sementara kantong penuh berarti pemberdayaan masyarakat untuk meningkatkan penghasilan dan subsidi di berbagai bidang untuk meningkatkan kesejahteraan masyarakat agar sesuai kebutuhan hidup cukup.

Oleh karena itu pentingnya sebuah komunikasi politik yang baik, untuk memperoleh dukungan dari masyarakat, dalam hal ini peneliti membahas gubernur petahana Basuki Tjahaja Purnama - Djarot Saiful Hidayat sebagai calon gubernur yang bertarung pada pemilihan gubernur 2017 mampu menyusun strategi yang berbeda sebagai petahana untuk dapat memenangkan kampanye dan perolehan suara langsung dari masyarakat.

Berdasarkan latar belakang yang sudah peneliti paparkan diatas, maka peneliti memfokuskan penelitian pada : "Bagaimana strategi kampanye yang dilakukan calon gubernur petahana Basuki Tjahaja Purnama-Djarot Saiful Hidayat dalam menghadapi pemilihan gubernur 2017?”. Dari fokus penelitian diatas, maka tujuan dari penelitian ini adalah untuk mengetahui bagaimana strategi kampanye yang dilakukan calon gubernur petahana Basuki Tjahaja Purnama-Djarot Saiful Hidayat dalam menghadapi pemilihan kepala daerah DKI Jakarta / Gubernur 2017.

Kemudian beberapa konsep teori yang digunakan dalam penelitian ini adalah komunikasi politik, strategi politik, kampanye politik, serta teknik perencanaan dan aksi yang akan dijelaskan satu per satu berikut ini. Arifin Rahman mengungkapkan komunikasi politik merupakan salah satu input dari system politik, dimana politik ini menggambarkan proses informasi-informasi politik. Sedangkan menurut Alfian, komunikasi politik yang diasumsikan yang menjadi sistem politik itu hidup dan dinamis. Komunikasi politik mempersembahkan semua kegiatan dari sistem politik sehingga aspirasi dan kepentingan dikonversikan menjadi berbagai kebijaksanaan (T.A Pito, 2006).

Partai politik ini tidak terlepas dari yang namanya "strategi politik". Strategi politik merupakan teknik, cara atau strategi yang digunakan untuk mewujudkan suatu cita-cita politik, strategi politik sangat penting bagi setiap partai politik, tanpa adanya strategi politik maka perubahan jangka panjang sama sekali tidak akan terwujud. Perencanaan strategi suatu proses dan perubahan politik merupakan analisis yang gambling dari keadaan kekuasaan, sebuah 
gambaran yang jelas mengenai tujuan akhir yang ingin dicapai, dan juga segala kekuasaan untuk mencapai tujuan tersebut (T.A Pito, 2006).

Kampanye politik secara universal dapat didefenisikan sebagai suatu cara yang digunakan para warga dalam demokrasi untuk menentukan siapa yang akan memerintah mereka. Menurut Pasal 1 butir 11 Undang-Undang No. 12 tahun 2003 (Pemilu Legislatif) kampanye pemilu adalah kegiatan proses pemilu dan atau calon anggota Dewan Perwakilan Rakyat (DPR), DPRD Propinsi, dan DPRD Kabupaten dan Kota untuk meyakinkan para pemilih dengan menawarkan program-programnya. Pemilihan kepala daerah atau yang biasa disebut PILKADA atau Pemilukada dilakukan secara langsung oleh penduduk daerah administratif setempat yang memenuhi syarat. Pemilihan kepala daerah dilakukan satu paket bersama dengan wakil kepala daerah. Kepala daerah dan wakil kepala daerah yang antara lain Gubernur dan wakil gubernur untuk provinsi, Bupati dan wakil bupati untuk kabupaten, serta Wali kota dan wakil wali kota untuk kota.

Teori perencanaan dalam bidang komunikasi ini dikembangkan oleh Charles Berger. Teori ini menjelaskan tentang proses perencanaan individu atau seseorang dalam perilaku komunikasi. Menurut Berger rencana adalah penyataan dari tujuan yang diarahkan untuk suatu rangkaian tindakan dengan kata lain, rencana adalah gambar dari salah satu langkah yang akan dilalui untuk memenuhi tujuan (Littlejohn, 2001). Perencanaan adalah proses berpikir atau rencana aksi, komunikasi sangat penting dalam mencapai tujuan.

John Greene dalam teorinya action assembly theory menjelaskan tentang cara seseorang mengorganisasikan pengetahuan dengan pikiran dan menggunakannya untuk membentuk pesan (Littlejohn, 2001). Teori ini menjelaskan struktur dan proses tersebut dalam aksi komunikatif. Teori ini menguji cara pengetahuan yang diurutkan dan digunakannya dalam komunikasi. Dari teori kumpulan aksi yang dikembangkan oleh John Greene, terdapat beberapa asumsi dasar. Dalam teori ini, Greene menyebut 2 komponen pengetahuan, yakni pengetahuan isi (content knowledge) dan pengetahuan procedural (procedural knowledge). Pengetahuan prosedural terdiri dari suatu kesadaran akan konsekuensi dariberbagai aksi dalam situasi-situasi yang berbeda.

\section{Metode Penelitian}

Metode yang digunakan adalah deskriptif kualitatif, yaitu suatu prosedur penelitian yang menggunakan data deskriptif berupa kata-kata tertulis atau lisan dari orang-orang dan pelaku yang dapat diamati. Pendekatan kualitatif, yaitu suatu prosedur penelitian yang menghasilkan data deskriptif berupa ucapan atau tulisan dan prilakuyang dapat diamati dari subyek itu sendiri. Pengumpulan data untuk mengumpulkan data dilapangan dalam rangka menjawab fokus penelitian, mempergunakan metode pengumpulan data sebagai berikut: (1) wawancara; (2) observasi.

Tujuan dari penelitian ini adalah untuk mengetahui strategi kampanye Basuki Tjahaja Purnama - Djarot Saiful Hidayat pada Pemilihan Gubernur DKI Jakarta 2017. Dalam pelaksanaannya, peneliti akan mengumpulkan data dari wawancara dengan : (1) Tim Sukses pasangan calon Basuki Tjahaja Purnama - 
Djarot Saiful Hidayat (Partai Solidaritas Indonesia), Rajajuli Antoni, Ph. D; (2) Pengamat Politik (Direktur Lembaga Analisis Politik Indonesia), Maksimus Ramses Lalongkoe, S.Sos, M.Sc; (3) Jurnalis Televisi ( Produser Kompas TV), Riko Anggara, S.Sos.

\section{Hasil Penemuan Dan Diskusi}

\section{Teori Planning and Action dalam Strategi Kampanye Gubernur Petahana Basuki Tjahaja Purnama - Djarot Saiful Hidayat}

Berbagai macam strategi yang digunakan oleh pasangan calon Basuki Tjahaja Purnama - Djarot Saiful Hidayat telah dijabarkan oleh tim pemenangan, melalui wawancara mendalam dengan peneliti. Disamping wawancara tersebut, peneliti juga melakukan studi kepustakaan melalui sumber website resmi pasangan calon Basuki Tjahaja Purnama - Djarot Saiful Hidayat untuk mendapatkan data - data tentang program yang sudah dan akan dilakukan oleh pasangan ini. Dan program - program yang disusun oleh pasangan Basuki Tjahaja Purnama - Djarot Saiful Hidayat akan dikaitkan oleh peneliti dengan teori perencanaan dan aksi yang telah dibahas dalam bab sebelumnya.

Dalam teori perencanaan oleh Charles Berger terdapat beberapa asumsi dasar yang antara lain adalah teori Berger yang pertama adalah menunjukkan bahwa apakah besar dan kecilnya keberhasilan bergantung pada motivasinya untuk mencapai tujuan. Sebuah rencana akan matang dan mempunyai kemungkinan besar untuk berhasil apabila mempunyai motivasi yang kuat. Sebaliknya, jika motivasi untuk mencapai tujuannya rendah, akan mungkin terjadi kegagalan. Teori ini sesuai dengan program yang dilakukan oleh pasangan Basuki Tjahaja Purnama - Djarot Saiful Hidayat untuk warga berkebutuhan khusus. Kepedulian Basuki Tjahaja Purnama kepada warga berkebutuhan khusus membuat Basuki Tjahaja Purnama termotivasi untuk memperhatikan kebutuhan kaum difabel bahkan juga memberi jaminan pendidikan untuk mereka. Seperti yang diungkapkan Basuki Tjahaja Purnama melalui situs resminya.

"Saya kira yang penting temukan anak-anak ini. Mereka harus bisa bergaul. Dia itu istimewa. Lurah mesti urus." (https://ahokdjarot.id/program/sosial/)

Maka dari itu Basuki Tjahaja Purnama - Djarot Saiful Hidayat memasukkan kasus ini dalam programnya yang tertulis pula dalam website resmi mereka, tentang penunjang fasilitas untuk warga berkebutuhan khusus seperti berikut ini: (1) Melakukan identifikasi warga berkebutuhan khusus. Ahok-Djarot akan bekerjasama dengan kelurahan untuk mendata warga berkebutuhan khusus. Dengan begitu, pemerintah dapat memberikan bantuan yang tepat agar mereka dapat melakukan aktivitas sehari-hari dengan nyaman. (2) Membangun Sekolah Luar Biasa agar mencukupi kebutuhan siswa-siswi berkebutuhan khusus. Jumlah SLB yang ada belum mencukupi untuk melayani siswa-siswi Jakarta yang berkebutuhan khusus. Ahok-Djarot akan mendorong pembangunan SLB agar seluruh anak bisa mendapatkan hak pendidikan yang sama. Hal tersebut menunjukkan bahwa teori "planning" Berger berkaitan erat dengan strategi yang 
digunakan Basuki Tjahaja Purnama - Djarot Saiful Hidayat dalam penyusunan program - programnya.

Selanjutnya adalah teori aksi oleh Greene yang pertama adalah dimana terdapat beberapa asumsi dasar dan salah satunya adalah untuk melakukan suatu yang baik tidak hanya membutuhkan pengetahuan dan motivasi saja, tetapi juga kemampuan untuk mengatur dan mengambil tindakan yang diperlukan secara efisien dan tepat. Hal ini apabila dikaitkan dengan program Basuki Tjahaja Purnama - Djarot Saiful Hidayat maka sesuai dengan program yang telah dilakukan seperti dibawah ini seperti memperhatikan kebutuhan kaum difabel dalam merevitalisasi trotoar. Basuki Tjahaja Purnama - Djarot Saiful Hidayat telah menerapkan prinsip ramah difabel dalam revitalisasi trotoar yang dilakukan baru-baru ini. Trotoar dibuat lebih lebar dan dibuat dalam bentuk $\mathrm{S}$ terbalik, sehingga kursi roda pun bisa lewat dengan nyaman. Tidak hanya itu, kaum difabel juga bisa menikmati layanan bus TransJakarta dengan gratis (https://ahokdjarot.id/program/sosial/). Disini terlihat bahwa pasangan Basuki Tjahaja Purnama - Djarot Saiful Hidayat juga mempelajari apa saja yang menjadi kebutuhan kaum difabel. Sehingga dalam program yang telah dilaksanakan, pasangan ini dapat memberika bantuan yang tepat untuk masyarakat dan langsung bisa dirasakan manfaatnya.

Lalu yang kedua dari asumsi dasar yang digunakan dalam teori planning Berger adalah kekuatan tujuan akan mempengaruhi rencana yang cenderung kompleks. Asumsi ini menyatakan ketika tujuannya kuat, tentu saja akan mempengaruhi rencana yang dimiliki tentang rencana dan pengetahuan dalam pelaksanaan aksi. Hal ini dikaitkan oleh peneliti tentang program unggulan Basuki Tjahaja Purnama - Djarot Saiful Hidayat tentang Basuki Tjahaja Purnama sendiri yang mengungkapkan tujuannya tentang membuat ruang untuk keluarga keluarga berkumpul dan berbagi tentang masalah rumah tangga. Ia sendiri sangat menginginkan hal ini karena dengan adanya ruang terbuka maka akan banyak warga yang bisa menggunakannya untuk berbagai macam kegiatan. Seperti yang diungkapkannya melalui website resmi pasangan Basuki Tjahaja Purnama Djarot Saiful Hidayat.

"Kenapa penting komunitas seperti ini? Semua rumah tangga pasti punya kesulitan masingmasing. Untuk itu kami butuh komunitas untuk berkumpul. Untuk mengetahui bermacammacam masalah keluarga-keluarga (https://ahokdjarot.id/program/penataan-kota/)."

Karena tujuan Basuki Tjahaja Purnama sangat kuat dalam hal penataan kota Jakarta, maka Basuki Tjahaja Purnama memasukkan beberapa rencana terkait program pembukaan Ruang Terbuka Hijau (RTH) atau Ruang Publik Terpadu Ramah Anak (RPTRA). Antara lain adalah sebagai berikut rencana yang akan dilakukan oleh pasangan Basuki Tjahaja Purnama - Djarot Saiful Hidayat: (1) Melakukan pembangunan Ruang Publik Terpadu Ramah Anak (RPTRA) sebanyak 500 buah. Ahok-Djarot akan melanjutkan pembangunan RPTRA untuk memenuhi rasio sebanyak 3 unit per kelurahan. Area ini dapat menjadi salah satu pusat kegiatan untuk warga sekitar. Sasaran pembangunan RPTRA adalah kawasan padat penduduk area itu dapat menjadi pusat interaksi warga. (2) Menambah ketersediaan Ruang Terbuka Hijau (RTH). Ahok-Djarot ingin memastikan perbandingan gedung dengan ruang terbuka tetap seimbang. Oleh 
karenanya, pemerintah akan melakukan pembelian lahan. Lahan tersebut kemudian akan dikelola menjadi RTH. Hal ini menunjukkan bahwa rencana yang kuat akan mempengaruhi rencana dan pada akhirnya adalah tujuan yang ingin dicapai. Yang mana berarti hal ini sesuai dengan asumsi dasar teori planning yang diungkapkan oleh Berger.

Sementara itu asumsi dasar dari teori action Greene adalah adanya keseimbangan tindakan menurut teori ini, kesinambungan tindakan merupakan suatu proses yang rumit dan tidak selalu berhasil. Untuk melakukan suatu yang baik tidak hanya membutuhkan pengetahuan dan motivasi saja, tetapi juga kemampuan untuk mengatur dan mengambil tindakan yang diperlukan secara efisien dan tepat. Hal ini juga didukung dengan program yang telah dilakukan oleh pasangan Basuki Tjahaja Purnama - Djarot Saiful Hidayat antara lain seperti (https://ahokdjarot.id/program/penataan-kota/): (1) Melakukan pembangunan RPTRA sebanyak 188 buah dan telah meresmikan 70 buah. Pembangunan RPTRA tidak menggunakan APBD, melainkan murni dari dana CSR. Setiap RPTRA dilengkapi fasilitas seperti ruang laktasi, ruang baca, fasilitas olahraga, toilet umum, toilet difabel dan CCTV. (2) Membenahi Kalijodo menjadi kawasan RTH. Sebelumnya, Kalijodo merupakan kawasan lokalisasi. Ahok-Djarot telah melakukan penertiban terhadap warga sekitar dan membenahi area itu sehingga bisa menjadi ruang terbuka hijau, untuk pusat aktivitas warga. Jadi tidak hanya dengan memiliki motivasi yang kuat saja tetapi program ini juga telah mengambil tindakan yang tepat dan efisien sehingga hal ini dapat disebut sesuai dengan asumsi dasar teori action Greene.

\section{Simpulan}

Berdasarkan serangkaian penelitian yang dilakukan dari analisis teori komunikasi, paradigma, hingga wawancara yang telah dilakukan. Maka terdapat beberapa kesimpulan sebagai berikut. Pertama, strategi kampanye yang dilakukan gubernur petahana Basuki Tjahaja Purnama adalah dengan media kampanye mulai video, poster, meme, menembus partai - partai politik dan bahkan door to door kepada masyarakat. Mereka juga memiliki pasukan di media sosial untuk membantu sosialisasi secara efektif kepada masyarakat. Pasangan ini juga menyasar media baru dengan melakukan flash mob dan menandai ciri khas mereka dengan baju khas kotak-kotak Basuki Tjahaja Purnama - Djarot Saiful Hidayat.Pasangan ini juga memiliki media monitoring, baik media social maupun media konvensional monitoring. Sehingga dari media - media tersebut mereka bisa menngetahui isu negatif apa yang sedang dimainkan oleh lawan. Lalu setelah itu mereka bisa merumuskan strategi untuk digunakan esok harinya atau isu apa yang akan mereka lempar.

Kedua, calon pemilih yang disasar oleh pasangan Basuki Tjahaja Purnama - Djarot Saiful Hidayat adalah calon pemilih rasional yang lebih mementingkan logika. Dan didekati dengan metode pendekatan rasional pula dengan menunjukkan track record atau bukti program nyata.

Ketiga, program - program nyata yang sudah dilakukan oleh pasangan Basuki Tjahaja Purnama - Djarot Saiful Hidayat menjadi senjata yang digunakan 
pasangan ini untuk mendapatkan keyakinan dari calon pemilih seperti contohnya mengubah lokasisasi menjadi Ruang Publik Terpadu Ramah Anak di berbagai kawasan untuk kenyamanan masyarakat sekitar dan juga pemberdayaan kaum disabilitas yang akan makin ditingkatkan setelah mereka terpilih kembali.

\section{Ucapan Terima Kasih}

Puji syukur kepada Tuhan Yang Maha Kuasa, yang telah memberikan berkat dan rahmat-Nya kepada penulis dalam menyelesaikan penyusunan penelitian ini. Penelitian ini dapat terwujud berkat bantuan dari berbagai pihak, baik secara langsung maupun tidak langsung. Oleh karena itu, pada kesempatan ini penulis ingin mengucapkan terima kasih disertai penghargaan yang setinggitingginya kepada pihak-pihak yang telah membantu, pihak- pihak tersebut ialah:

1. Teman-teman di FIKOM Universitas Mercu Buana

2. Dadan Iskandar, M.Si sebagai teman diskusi

3. Para narasumber yang telah meluangkan waktunya.

\section{Daftar Pustaka}

Firmanzah. (2008). Marketing Politik: Antara Pemahaman dan Realitas. Jakarta: Yayasan Obor Indonesia.

Littlejohn, Stephen W. (2001. Theories of Human Communication. Belmont, USA: Wadsworth Group.

T. A Pito. (2006). Mengenal Teori-Teori Politik. Bandung: Nuansa.

Academia. (2016). Wacana Pemilihan Gubernur dan Bupati Walikota Dalam RUU Pilkada. Diakses pada tanggal 6 Februari 2017. Data tersimpan di: http://www.academia.edu/3654706/Wacana_Pemilihan_Gubernur_Bupati_ Walikota_Oleh_DPRD_dalam_RUU_PILKADA.

Ahok-Djarot. (n.d.). Mengenal Sosok Ahok Si Calon Petahana. Diakses pada tanggal 6 Februari 2017. Data terarsip di: https://ahokdjarot.id/media/mengenal-sosok-ahok-si-calon-petahana. 